\title{
ASSESSMENT OF URBAN TRANSPORT - A COMPARATIVE ANALYSIS OF SELECTED CITIES BY TAXONOMIC METHODS
}

\author{
StAWOMIRA HAJDUK
}

\begin{abstract}
A B S T R A C T
This paper aims to perform comparative analysis of urban transport in selected global cities and to verify the existence of clusters. It was based on data source from the World Organization Data Urban. It used Indicators proposed in ISO 37120 Sustainable Community Development.

The test procedure exploited taxonomic methods as Ward's hierarchical analysis and the deagglomerating k-means analysis. The empirical analysis comprises four indicators: (I) high capacity public transport system, (II) light passenger public transport system, (III) annual number of public transport trips and (IV) number of personal automobiles.

Main results are the classification of selected global cities, identification and characterization of trends in the field of urban transport in each group. The empirical analysis confirms a substantial diversity of urban transport in selected cities. These differences arise from their past, geographical location, size, different reactions to the transition process and the different economic structures. The taxonomic analysis of the urban transport in selected cities separated five independent classes typological. This elaboration aims to examine the role of urban transport in city management based on a literature review, databases and reports of the European Union.
\end{abstract}

KEY WORDS

urban transport, ISO 37120, smart city, taxonomic, city management

DOI: 10.1515/emj-2016-0034
Corresponding author:

Sławomira Hajduk

Bialystok University of Technology, Faculty of Management, Department of Tourist Economy, Poland

e-mail: s.hajduk@pb.edu.pl

\section{INTRODUCTION}

Urban transport is a significant component of city management used worldwide. Sustainable public transport prevents social exclusion, congestion, and air pollution in cities. However, so far there has been no standardized method to measure the quality of life and delivery of public services in cities. ISO 37120 Sustainable Community Development provides a uniform and consistent approach to measurement methods of city performance. Urban transport is one of 17 thematic areas.

The main goal of the study is to determine trends in the field of urban transport, to classify global cities and to verify the existence of clusters. The article consists of four sections. The first part includes deliberations of the scientist concerning urban transport. 
The next sections present the data and research methods. The last two parts of the study contain results and conclusions of the examination. The elaboration was based on literature studies and taxonomic analysis. The data obtained from the database of the Central Statistical Office - Local Data Bank, Eurostat Regional Statistics and the World Organization Data Urban.

\section{LITERATURE REVIEW}

A constantly growing number of urban residents makes access to public service more difficult and, consequently, reduces the quality of life (Mucha, 2012). Currently, 54\% of the world's population resides in cities, whereas forecasts indicate an increase of up to $66 \%$ in 2050 (United Nations, 2015). Approximately $85 \%$ of the EU's GDP is generated in cities (Dobbs et al., 2012). The increase in road traffic as well as passenger and freight transport, cause congestion and air pollution. Urban transport became an important component of city management in international documents in the last decade (Table 1). Forecasts of the European Commission show that the intensity of freight transport will increase by $40 \%$ by 2030 , and by more than $80 \%$ by 2050 , when compared to 2005. At the same time, it is expected that passenger transport will also increase by about $34 \%$ by 2030 , and by more than $50 \%$ by 2050 , in comparison to 2005 (White Paper, 2011). Based on the result of a study conducted in seven major Polish cities, it is estimated that in 2013, costs related to congestion will reach PLN 3.5 billion (average of 2.905 per driver). Additionally, external costs of accidents in urban areas are estimated at EUR 80 billion per year, and the external costs of noise - at EUR 40 billion per year. Furthermore, $\mathrm{CO}_{2}$ emissions in urban areas amount to 280 million tons per year (Rzepnikowska et al., 2014).

City management in the field of urban logistics is influenced by the regulations at the European Union level (Table 1). The European Commission has developed several documents imposing on the cities the obligation to take action towards the improvement of passenger and freight traffic in the city and to reduce environmental degradation. One of the requirements of the EU towards the member states is the necessity to develop sustainable mobility strategies, including passenger and freight transport. Unfortunately, many cities have not prepared this document (Allen et al., 2015; Przybyłowski, 2014).
Tab. 1. Transport on the background of domains of city management in international documents

\begin{tabular}{|l|l|}
\hline \multicolumn{1}{|c|}{ DocUMENTS } & \multicolumn{1}{c|}{ DomaINS OF CITY MANAGEMENT } \\
\hline $\begin{array}{l}\text { Pact of } \\
2016\end{array}$ & $\begin{array}{l}\text { Inclusion of migrants and refugees; Air } \\
\text { quality; Urban poverty; Housing; Circular } \\
\text { economy; Jobs and skills in the local } \\
\text { economy; Climate adaptation (including } \\
\text { green infrastructure solutions); Energy } \\
\text { transition; Sustainable use of land and } \\
\text { Nature-Based solutions; Urban mobility; } \\
\text { Digital transition; Innovative and responsible } \\
\text { public procurement }\end{array}$ \\
\hline ISO 37120, & $\begin{array}{l}\text { Economy, Education, Energy; Finance; } \\
\text { Environment; Fire and emergency response; } \\
\text { Governance; Health; Recreation; Safety; } \\
\text { Shelter; Solid waste; Telecommunication; } \\
\text { Transportation; Urban planning; Wastewater; } \\
\text { Water sanitation }\end{array}$ \\
\hline $\begin{array}{l}\text { Leipzig } \\
\text { Charter, 2007 }\end{array}$ & $\begin{array}{l}\text { Energy efficiency; Environment; Labor } \\
\text { market; Education; Urban transport }\end{array}$ \\
\hline Bristol \\
Accord, 2005
\end{tabular}

Source: author's elaboration based on (Urban Agenda ..., 2016; ISO 37120 ..., 2015; Leipzig Charter ..., 2007; Bristol Accord ..., 2005).

Integrated city management requires specific knowledge of how to take effective strategic decisions. Effective city management is based on information that can be obtained through quick access to reliable data. A smart city should be built through the implementation of goals and decisions based on reliable data. ISO 37120 should be used to measure the city performance. The standard value does not include evaluation data and quantitative limits; it only provides a framework for the sustainable development of the city and its monitoring. It allows to compare cities in a global perspective and to benefit from the knowledge and skills of the leading urban centres. This is the right tool for reporting the state of city development. There are four levels of accreditation certificate. The minimum limit is to collect data for 30 obligatory indicators. World Organization Data Urban disseminates a new international standard for cities and coordinates efforts to obtain accreditation by sharing city data. It publishes information regarding 30 cities.

Sustainable urban transport improves the quality of life in urban areas. The results are a wide range of advantages, such as a more attractive public space, improvement in the city's image and increase in competitiveness, health improvement, better road safety, lower air pollution and reduced noise emissions (Komisja Europejska, 2014). Improving the 
quality of urban space can be achieved through the promotion of public transport and alternative forms of movements within the cities (Ministerstwo Infrastruktury i Rozwoju, 2015). It may help to inhibit the process of suburbanization and revitalize city centres. Road investments should mainly focus on the construction of a basic transport system of the city and its functional area, which will enable the removal of excessive traffic through the ring roads of the city and exit routes to national roads. It is necessary to modernize the existing road system by eliminating bottlenecks and improving traffic safety, which is the priority of public transport and cycling.

Improvement of urban mobility can also be achieved through the appropriate coordination of timetables among different means of transport. The integration of railways, subways, buses, and trams requires, among other things, a rhythmic timetable, dynamic passenger information, and proper interchanges locations. This solution constitutes a part of the category of a multi-modal trip, which is to leave the personal means of transport in the car park and to continue the onward journey to the city centre by public transport. It is also worth mentioning here the existence of an Intelligent Transportation Systems, which allows for the management of road traffic, rail, public transport, fleet and cargo transport. These are devices that can investigate and inform drivers about traffic jams or vacant parking spaces.

The public transport measurement is rather challenging because of a diversified approach to this matter in the substantive literature and various international and national strategic documents (European Commission, 2013). However, it is possible to determine and select the indicators that are commonly and repeatedly applied in the very approach to the measurement of the progress of implementation of public transport. The quantitative approach of the measurement applicable to the transport phenomena is generally easier to measure directly. Quantitative data refer to information measured numerically (Mingardo, 2008; Pindea, 2016). Quantitative data are recognized as more objective and easier to be analysed, e.g. the speed of moving vehicles and their communication delays. The qualitative approach measurement of specific phenomena of transport is more difficult to estimate. The qualitative data are related to a different type of information, e.g. convenience, comfort, and dynamism in the opinion of users (Nieuwenhuijsen, 2016). Qualitative data can be expressed as quantitative, using a rating system or different evaluation techniques used in economics. Another division of indicators is reflecting the economic, social and environmental influences. Economic dimension indicates the profitability of transport, as the cost per unit of travel (Fielbaum et al., 2016; Taylor, 2008; Medda et al., 2003). The social dimension reflects the relative mobility and financial burden of the population in connection with the use of transport. The environmental dimension shows different emissions caused by transport and field requirements (Table 2).

The great challenge in the field of urban transport is to reduce the use of cars in favour of alternative forms of movement, which have a positive environmental impact, such as a cycling or walking. Furthermore, alternative forms of movement reduce congestion, at the same time improving health and physical condition of travellers. Poles have about 9 million bicycles but in large cities, cycling remains at a low level, constituting 1-3\% of total journeys. To compare, in some European cities, such as Kuopio, Cambridge, Stralsund, cycling amounts to $30 \%$ of total journeys (Fig. 1).

Tab. 2. Approach and domains of urban transport in scientific literature

\begin{tabular}{|c|c|c|c|}
\hline \multicolumn{2}{|c|}{ APPROACH BASED ON QUANTITATIVE DATA } & \multicolumn{2}{|c|}{ APPROACH BASED ON QUALITATIVE DATA } \\
\hline \multicolumn{2}{|c|}{$\begin{array}{l}\text { - user preferences } \\
\text { - convenience and comfort } \\
\text { - the dynamics of community } \\
\text { - } \text { aesthetic qualities }\end{array}$} & \multicolumn{2}{|c|}{$\begin{array}{l}\text { - length of linear infrastructure } \\
\text { - } \text { the number of kilometres travelled per vehicle and per person } \\
\text { - } \quad \text { traffic accidents and fatalities } \\
\text { - } \quad \text { expenses and revenues }\end{array}$} \\
\hline MOBILE DIMENSION & ECONOMIC DIMENSION & SOCIAL DIMENSION & ENVIRONMENTAL DIMENSION \\
\hline $\begin{array}{l}\text { - } \quad \text { the supply of transport } \\
\text { service } \\
\text { - } \quad \text { the organisation of } \\
\text { mobility inside city }\end{array}$ & $\begin{array}{l}\text { - cost incurred by } \\
\text { community }\end{array}$ & $\begin{array}{l}\text { - the number of } \\
\text { vehicles in the } \\
\text { household } \\
\text { - } \text { the distance flown } \\
\text { individually } \\
\text { - expenditure by } \\
\text { households on } \\
\text { transport }\end{array}$ & 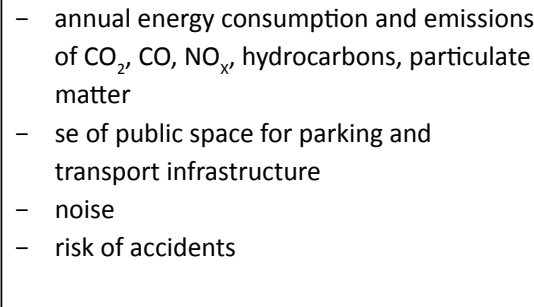 \\
\hline
\end{tabular}




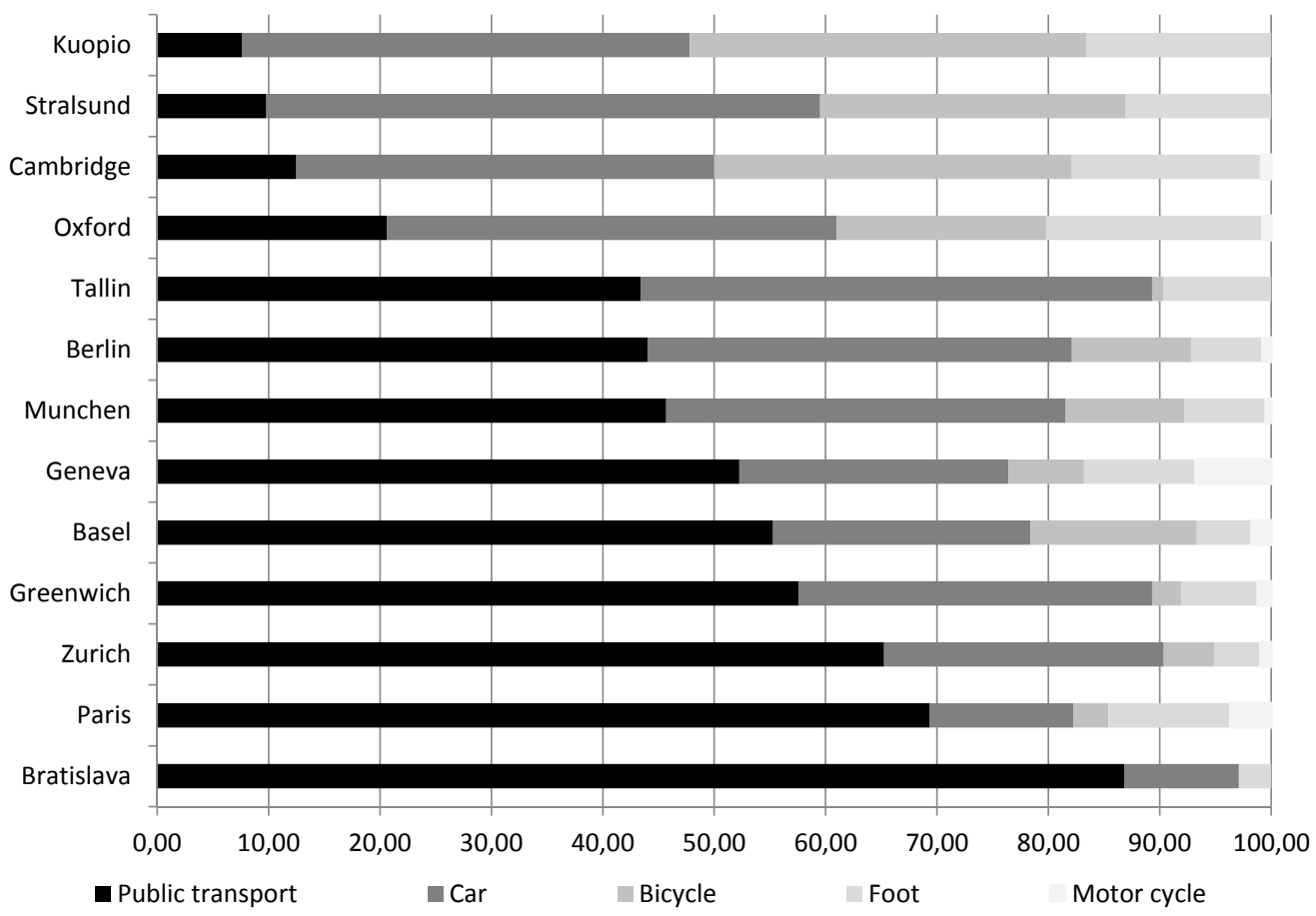

Fig. 1. Share of the use of transportation modes in European cities [\%]

Source: author's elaboration based on (Eurostat, 2016).

The collective public transport uses several systems of transport: bus, tram, railway, trolleybus, and metro. In relation to passenger cars, it brings two important advantages - reduces traffic congestion and environmental impact. Compared to individual transport, a bus emits five times less pollution, requires three times less energy per passenger, and twenty times less road surface. A particularly advantageous solution in this respect is bus lanes. 24 Polish cities with powiat status have $196 \mathrm{~km}$ of bus lanes allocated for public transport vehicles (Table 3 ).

Tab. 3. Cities with powiat status with the greatest length of bus lanes

\begin{tabular}{|l|c|c|c|}
\hline \multicolumn{1}{|c|}{ CITIES } & $\begin{array}{c}\text { LENGTH OF } \\
\text { BUS LINES }\end{array}$ & $\begin{array}{c}\text { NUMBER } \\
\text { OF BUSES }\end{array}$ & $\begin{array}{c}\text { BUSES LINES } \\
\text { PER 100 BUSES }\end{array}$ \\
\hline Kielce & 15.3 & 576 & 2.66 \\
\hline Olsztyn & 13.3 & 657 & 2.02 \\
\hline Białystok & 12.8 & 857 & 1.49 \\
\hline Łódź & 18.9 & 1363 & 1.39 \\
\hline Kraków & 25.2 & 2458 & 1.03 \\
\hline Wrocław & 21.5 & 2129 & 1.01 \\
\hline
\end{tabular}

Source: author's elaboration based on (Bank Danych ..., 2016).

Moreover, many scientists analyse transport in a national and regional approach (Czech \& Lewczuk,
2016). There are only few publications that compare transport in cities. Urban transport often appears in case studies (Paradowska, 2012; Zimon \& Gosik, 2015), analyses of the key success factors (Iwan, 2015) or benchmarking (Chojnacka, 2012; Szymczak \& Sienkiewicz-Małyjurek, 2011; Kiba-Janiak, 2016). Scientists use the latest future-oriented methods to evaluate transport (Ejdys et al., 2015).

\section{RESEARCH METHODS}

The presented research focused on the assessment of urban transport. The scope of research has three steps: selection, evaluation, and classification (Fig. 2). Four indicators were selected from ISO 37120:2014, namely: $\left(\mathrm{X}_{1}\right)$ kilometres of high capacity public transport system per 100000 population; $\left(\mathrm{X}_{2}\right)$ kilometres of light passenger public transport system per 100000 population; $\left(\mathrm{X}_{3}\right)$ the annual number of public transport trips per capita; and $\left(\mathrm{X}_{4}\right)$ the number of personal automobiles per capita.

The study included 25 cities (Table 4) with different levels of certification according to ISO 37120:2014, i.e. aspiring (the cities), gold (three cities), and platinum (12 cities). They represent each continent: six cities were European, ten - North American, one - 


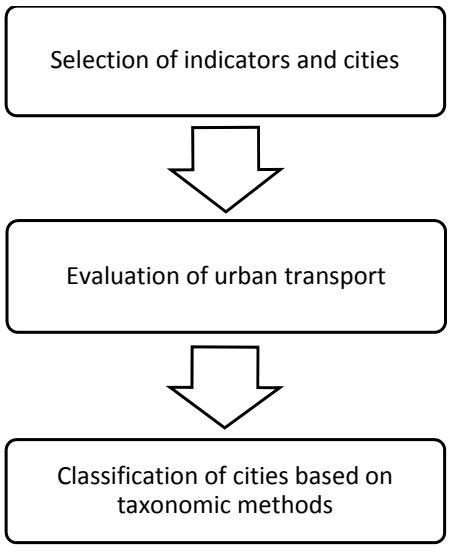

Fig. 2. Scope of the research process

South American, five - Asian, two - Australian, and one - African. Data for each city were collected from the website of the World Organization Data Urban (World Council ..., 2016).

Tab. 4. Certification level of cities per ISO 37120:2014

\begin{tabular}{|l|l|}
\hline $\begin{array}{c}\text { LeVEL OF } \\
\text { CERTIFICATION IN } \\
\text { ISO 37120:2014 }\end{array}$ & \multicolumn{1}{c|}{ CITIES AND ABBREVIATIONS } \\
\hline Aspiring & $\begin{array}{l}\text { ES1 Barcelona; NL2 Rotterdam; US2 LoS } \\
\text { Angeles; CA1 Surrey; CA4 Toronto; CA5 } \\
\text { Vaughan; AU1 Greater Melbourne; AE1 } \\
\text { Dubai; VN1 Haiphong; TW1 Amman }\end{array}$ \\
\hline Gold & $\begin{array}{l}\text { NL1 Amsterdam; PT1 Porto; CA3 } \\
\text { Shawinigan }\end{array}$ \\
\hline Platinum & $\begin{array}{l}\text { UK1 London; ES2 Valencia; US1 Boston; } \\
\text { US3 San Diego; CA2 Saint-Augustin-de- } \\
\text { Desmaures; MX1 Guadalajara; MX2 Leon; } \\
\text { AR1 Bueno Aires; AU2 Melbourne; PH1 } \\
\text { Makati; JO1 Taipei; SA1 Makkah. }\end{array}$ \\
\hline
\end{tabular}

Abbreviations of cities based on ISO 3166 .

Source: author's elaboration based on (World Council ..., 2016).

Each indicator was determined by measuring the position (arithmetic mean,) and variability (standard deviation, $\mathrm{S}_{\mathrm{X}}$; variation coefficient, V). Indicators were standardized based on formula. The Pearson's correlation coefficient matrix was used to determine the correspondence among indicators and to eliminated strongly correlated indicators. The classification of cities applied the Ward's hierarchical analysis for the Euclidean distance based on formula. The number of classes was determined by using a graph of distance bond with respect to binding steps. Each aggregation was characterized based on the deagglomerating k-means method.

\section{RESEARCH RESULTS}

The most differentiated indicator (177.82\%) is the length of high capacity public transport system. While the least differentiated variable $(48.93 \%)$ is the number of public transport trips. Melbourne has the longest public transport system. Bueno Aires has the largest number of personal automobiles per capita (Table 5).

Tab. 5. Selected statistics of urban transport indicators

\begin{tabular}{|l|c|c|c|c|}
\hline & $\mathbf{x}_{\mathbf{1}}$ & $\mathbf{x}_{\mathbf{2}}$ & $\mathbf{x}_{\mathbf{3}}$ & $\mathbf{x}_{\mathbf{4}}$ \\
\hline & 11.64 & 121.54 & 316.22 & 0.42 \\
\hline $\mathrm{S}_{\mathrm{x}}$ & 20.70 & 90.35 & 454.65 & 0.21 \\
\hline $\mathrm{V}$ & 177.82 & 74.34 & 143.77 & 48.93 \\
\hline Max & AU2 102.87 & AU2 & PH1 & AR1 \\
& & 293.57 & 2097.25 & 0.75 \\
\hline \multirow{2}{*}{ Min } & CA1 CA2 PH1 & \multirow{2}{*}{ PH1 3.25 } & TW1 2.29 & VN1 \\
& TW1 SA1 0.00 & & & 0.01 \\
\hline
\end{tabular}

Source: author's elaboration based on (World Council ..., 2016).

Correlation among indicators was determined based on the Pearson's correlation coefficient (Table 6).

Tab. 6. Pearson's correlation matrix of urban transport indicators

\begin{tabular}{|l|c|c|c|}
\hline & $\mathbf{x}_{1}$ & $\mathbf{X}_{2}$ & $\mathbf{X}_{\mathbf{3}}$ \\
\hline $\mathrm{X}_{2}$ & 0.385836 & & \\
\hline $\mathrm{X}_{3}$ & 0.341173 & -0.057860 & \\
\hline $\mathrm{X}_{4}$ & 0.437447 & 0.348036 & -0.162726 \\
\hline
\end{tabular}

Source: author's elaboration based on (World Council ..., 2016).

Values of the correlation coefficient were positive except for two pairs. The strongest correlation was between the length of high capacity public transport system with the number of personal automobiles. Negative values of the correlation coefficient were observed in the following relations: the length of light passenger public transport system vs. the annual number of public transport trips as well as the annual number of public transport trips vs. the number of personal automobiles.

Using agglomeration Ward's method for the Euclidean distance, 25 cities were divided into five classes. Applying the chart that compares the binding distance chart to binding levels, the limiting distance was established at the level of 5.0. The taxonomic analysis of the urban transport in selected cities separated five independent typological classes. First and 


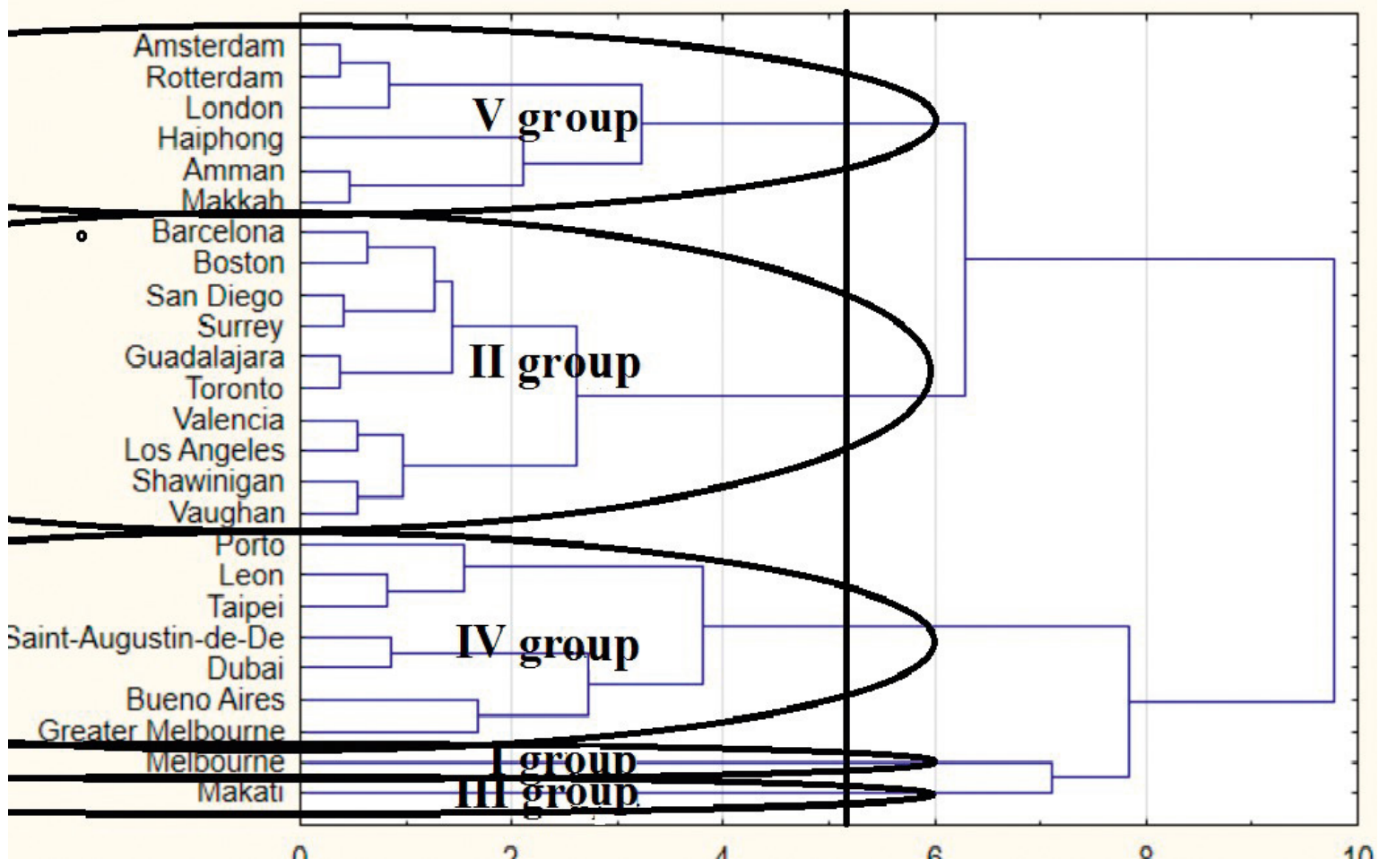

Fig. 3. Scheme of the cluster analyses

third class are constituted by a single element. The second group consists of ten mostly American and Canadian cities. The majority of European cities fall in the fifth class. The fourth cluster includes seven cities (Fig. 3).

Classes have been characterized using k-means methods. The first group has the highest capacity value of the public transport system, while the third cluster has the lowest. The first group has the highest value of the light passenger public transport system, while the third cluster has the lowest. The third cluster has the highest value of the annual number of public transport trips, while the second cluster has the lowest. The first group has the highest number of personal automobiles, while the third cluster has the lowest.

\section{DISCUSSION OF THE RESULTS}

The first group consists of one-element. Melbourne has a public transport system characterized by high levels of capacity. However, transport in Melbourne consists of an extensive network and a wide variety of transport services. The second class has ten objects, such as Barcelona, Valencia, Boston, San Diego, Los Angeles, Surrey, Shawinigan, Toronto, Vaughan, and Guadalajara. The cities have the lowest value for the light passenger public transport system. The third cluster consists of one element. Makati is characterized by high levels of the annual number of public transport trips because of jeepneys (they were introduced after the World War II and made from leftover US military jeeps in the Philippines). The fourth class includes seven objects, namely Porto, Leon, Taipei, Saint-Augustin-de-Desmaures, Dubai, Bueno Aires, and Greater Melbourne. These cities are characterized by the average value of all indicators. The fifth group consists of six objects: Rotterdam, Amsterdam, London, Haiphong, Amman, and Makkah. These cities are characterized by the average value of all indicators (Table 7).

Tab. 7. Average values of urban transport indicators for each group

\begin{tabular}{|l|c|c|c|c|}
\hline & $\mathbf{X}_{1}$ & $\mathbf{X}_{2}$ & $\mathbf{X}_{\mathbf{3}}$ & $\mathbf{X}_{4}$ \\
\hline Unites & $\mathrm{km}$ & $\mathrm{Km}$ & capita/yr & - \\
\hline GI & 102.87 & 293.57 & 1009.18 & 0.72 \\
\hline GII & 6.49 & 88.56 & 146.70 & 0.51 \\
\hline GIII & 1.10 & 3.24 & 2097.25 & 0.06 \\
\hline GIV & 11.47 & 220.94 & 314.03 & 0.49 \\
\hline GV & 6.99 & 51.58 & 188.98 & 0.21 \\
\hline
\end{tabular}

Source: author's elaboration based on (World Council ..., 2016). 


\section{CONCLUSIONS}

An efficient and effectively functioning transport in the city is important for residents and enterprises. As a part of the production and consumption, it is an integral part of the modern economy and society. However, apart from the positive impact transport also amounts to numerous social costs, including congestion, accidents, and negative impacts on the environmental.

The results obtained in this research show that selected cities are characterized by great diversity in the field of urban transport. These differences arise from their past, geographical location, size, different reactions to the transition process, and different economic structures. The taxonomic analysis of the urban transport in selected cities separated three independent typological classes (beyond the first and the third group, consisting of one element, respectively, Melbourne and Makai).

The author understands that due to the small sample and the huge variety of cities, generalised conclusions are hardly possible. However, the results of this study can be treated as guidance for reflection and further research.

\section{ACKNOWLEDGEMENTS}

The research was conducted within S/WZ/5/2015 project and was financed from Ministry of Science and Higher Education funds.

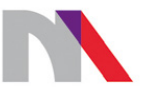

\section{Ministry of Science} and Higher Education

Republic of Poland

7th International Conference on Engineering, Project, and Production Management (EPPM2016) was financed in the framework of the contract no. 712/P-DUN/2016 by the Ministry of Science and Higher Education from the funds earmarked for the public understanding of science initiatives.

7th International Conference on Engineering, Project, and Production Management (EPPM2016) finansowana w ramach umowy 712/P-DUN/2016 ze środków Ministra Nauki i Szkolnictwa Wyższego przeznaczonych na działalność upowszechniającą naukę.

\section{LITERATURE}

Allen, J., Browne, M., \& Holguin-Veras, J. (2015). Sustainability Strategies for City Logistics. In A. McKinnon, M. Browne, M. Piecyk, A. Whiteing (Eds.), Green Logistics. Improving the Environmental Sustainability of Logistics (pp. 293-319). Kogan Page Publishers.

Bank Danych Lokalnych GUS [Local Data Bank Central Statistical Office]. (2016). Retrieved from https://bdl. stat.gov.pl/BDL/dane/podgrup/tablica

Bristol Accord. (2005). Retrieved from http://www.eib.org/ attachments/jessica_bristol_accord_sustainable_ communities.pdf

Chojnacka, M. (2012). Kryteria i metody oceny jakości obsługi klienta w wybranych przedsiębiorstwach transportu miejskiego. Prace Naukowe Uniwersytetu Ekonomicznego we Wrocławiu, 265, 65-76.

Czech, A., \& Lewczuk, J. (2016). Taxonomic and econometric analysis of road transport development in Poland - the voivodship approach. Ekonomia $i$ Zarzadzanie, 8(3), 79-88.

Dobbs, R., Remes, J., Manyika, J., Roxburgh, Ch., Smit, S., \& Schaer, F. (2012). Urban World: Cities and the Rise of the Consuming Class. McKinsey Global Institute. Retrieved from http://www.mckinsey.com/globalthemes/urbanization/urban-world-cities-and-therise-of-the-consuming-class

Ejdys, J., Nazarko, J., Nazarko, Ł., \& Halicka, K. (2015). Foresight application for transport sector. In M. Fiorini, \& J. Jia-Chon Lin (Eds.), Clean mobility and Intelligent Transport Systems (pp. 379-402). London, Great Britain: The Institution of Engineering and Technology.

European Commission. (2013). Together towards competitive and resource-efficient urban mobility. Retrieved from http://ec.europa.eu/transport/themes/urban/ doc/ump/com(2013)913_en.pdf

Eurostat. (2016). Retrieved from http://ec.europa.eu/eurostat/data/database

Fielbaum, A., Jara-Diaz, S., \& Gschwender, A. (2016). Optimal public transport networks for a general urban structure. Transportation Research Part B: Methodological, 94, 298-313.

ISO 3166. (2016). Retrieved from http://www.iso.org/iso/ home/standards/country_codes.htm

ISO 37120. (2015). Sustainable Development of Communities: Indicators for City Services and Quality of Life. Retrieved from http://publicaa.ansi.org/sites/apdl/ ANSI\%20Network\%20on\%20Smart\%20and\%20 Sustainable\%20Cities/ISO+37120-2014_preview_ final_v2.pdf

Iwan, S. (2015). Zarządzanie miejskim transportem towarowym w kontekście budowania konsensusu pomiędzy zróżnicowanymi oczekiwaniami jego interesariuszy. Prace Naukowe Uniwersytetu Ekonomicznego we Wrocławiu, 383, 223-235.

Kiba-Janiak, M. (2016). Kluczowe czynniki sukcesu logistyki miejskiej z perspektywy zarządzania miastem. Prace Naukowe Uniwersytetu Ekonomicznego we Wrocławiu, 420, 141-152. 
Komisja Europejska [European Commission]. (2014). Wytyczne. Opracowywanie i wdrożenie planu zrównoważonej mobilności miejskiej [Guidelines. Development and Implementation of the Plan of Sustainable urban mobility]. Retrieved from http://www.eltis. org/sites/eltis/files/BUMP_Guidelines_PL.pdf

Leipzig Charter on Sustainable European Cities. (2007). Retrieved from http://www.sarp.org.pl/pliki/karta_ lipska_pl.pdf

Medda, F., Nijkamo, P., \& Rietveld, P. (2003). Urban Land For Transport System and City Shapes. Geographical Analysis, 35(1), 46-57.

Mingardo, G. (2008). Cities and innovative urban transport policies. Innovation: Management, Policy \& Practice, 10, 269-281.

Ministerstwo Infrastruktury i Rozwoju [The Ministry of Infrastructure and Development]. (2015). Krajowa polityka miejska 2023 [National Urban Policy 2023]. Retrieved from http://www.mr.gov.pl/media/11579/ Krajowa_Polityka_Miejska_2023.pdf

Mucha, D. (2012). Jakość życia $w$ dużej aglomeracji miejskiej na przykładzie problemów transportowych Warszawy [Quality of life in the large urban agglomeration on the example of transport problems Warsaw]. Retrieved from http://www.siskom.waw.pl/siskom/Raport_ Jakosc_zycia_a_problemy_transportowe_Wawy_ Dominika_Mucha.pdf

Nieuwenhuijsen, M. (2016). Urban and transport planning, environmental exposures and health-new concepts, methods and tools to improve health in cities. Environmental Health: A Global Access Science Source, 15, 161-171.

Paradowska, M. (2012). China's Urban Transport. Challenges and Policy Issues. Research Papers of the Wroclaw University of Economic, 257,125-138.

Pindea, A. (2016). Disabilities, the design of urban transport systems and the city: a situational analysis. Universitas Humanistica, 81, 281-304.

Przybyłowski, A. (2014). Pomiar zrównoważonego rozwoju transport w polskich województwach [Measurement of Sustainable Transport Development in Polish Voivodship]. Optimum. Studia Ekonomiczne, 3(69), 184-194.

Rzepnikowska, M., Mikołajczak, R., Antczak, R., \& Bracik, A. (2014). Raport o korkach $w 7$ największych miastach Polski: Warszawa, Łódź, Wrocław, Kraków, Katowice, Poznań, Gdańsk [The Report of Traffic Jams in 7 the Largest Polish Cities: Warszawa, Łódź, Wrocław, Kraków, Katowice, Poznań, Gdańsk]. Deloitte Targeo. Retrieved from https://www2. deloitte.com/content/dam/Deloitte/pl/Documents/ Reports/pl_Raport_koszty_korkow_najwieksze_ polskie_miasta.pdf

Szymczak, M., \& Sienkiewicz-Małyjurek, K. (2011). Information in the City Traffic Management System. The Analysis of the Use of Information Sources and the assessment in terms of their usefulness for City Routes users. LogForum, 7(2), 37-50.

Taylor, M. (2008). Critical Transport Infrastructure in Urban Areas: Impacts of Traffic Incidents Assessed Using Accessibility-Based Network Vulnerability Analysis. Growth and Change, 39(4), 593-616.
United Nation. (2015). World urbanization prospect: the 2014 revision. Department of Economic and Social Affairs, Population Revision, New York. Retrieved from https://esa.un.org/unpd/wup/Publications/Files/ WUP2014-Report.pdf

Urban Agenda for the EU, Pact of Amsterdam (2016). Retrieved from http://ec.europa.eu/regional_policy/ sources/policy/themes/urban-development/agenda/ pact-of-amsterdam.pdf

White Paper. (2011). Roadmap to a Single European Transport Area - Towards a Competitive and Resource Efficient Transport System European Commission. Brussels, COM144 final. Retrieved from http:// ec.europa.eu/transport/themes/strategies/doc/2011 white_paper/white-paper-illustrated-brochure_pl. pdf

World Council on City Data Open Data Portal. (2016). Retrieved from http://open.dataforcities.org/

Zimon, G., \& Gosik, B. (2015). Ocena logistyki miejskiej w zakresie transportu zbiorowego na przykładzie Tomaszowa Mazowieckiego i Rzeszowa. Modern Management Review, 22, 197-209. 